\title{
Hypoxia-Responsive Root Hydraulic Conductivity Influences Soybean Cultivar-Specific Waterlogging Tolerance
}

\author{
Yutaka Jitsuyama \\ Research Group of Horticultural Science and Landscape Architecture, Division of Bioresources and Product Science, Hokkaido \\ University, Sapporo, Japan \\ Email: y-jitsu@res.agr.hokudai.ac.jp
}

How to cite this paper: Jitsuyama, Y. (2017) Hypoxia-Responsive Root Hydraulic Conductivity Influences Soybean CultivarSpecific Waterlogging Tolerance. American Journal of Plant Sciences, 8, 770-790. https://doi.org/10.4236/ajps.2017.84054

Received: January 27, 2017

Accepted: March 26, 2017

Published: March 30, 2017

Copyright $\odot 2017$ by author and Scientific Research Publishing Inc. This work is licensed under the Creative Commons Attribution International License (CC BY 4.0).

http://creativecommons.org/licenses/by/4.0/

\begin{abstract}
Excess soil moisture induces hypoxic conditions and causes waterlogging injury in soybean [Glycine $\max$ (L.) Merr.]. This study investigated the mechanism underlying the development of waterlogging injury. Nine Japanese soybean cultivars with varying degrees of waterlogging tolerance were grown in a hydroponic system for 14 days under hypoxic conditions. Shoot and root biomasses and root hydraulic conductivity were measured at an early vegetative stage for plants under control and hypoxic conditions. Root morphological traits and intramembrane aquaporin proteins were also analyzed. The tolerance of each cultivar to field waterlogging was based on biomass changes induced by the hypoxia treatment. Root hydraulic conductivity responses to hypoxia were associated with changes in total dry weight, leaf dry weight, and leaf area. The effects of hypoxic conditions on root hydraulic conductivity were also represented by the changes in root morphology, such as total root length, thick-root length, and number of root tips. Additionally, a $32.3 \mathrm{kDa}$ aquaporin-like protein seemed to regulate root hydraulic conductivity. Our results from a hydroponic culture suggest that the soybean cultivar-specific responses to hypoxic conditions in the rhizosphere reflect fluctuations in hydraulic conductivity related to root morphological or qualitative changes.
\end{abstract}

\section{Keywords}

Aquaporin, Hypoxia, Root Hydraulic Conductivity, Root Morphology, Soybean, Waterlogging Tolerance

\section{Introduction}

Prolonged heavy rain is generally a hindrance to agricultural production as it results in waterlogged soils [1]. Waterlogging can severely limit crop production 
in agricultural fields, especially in regions with high water tables and poor drainage because of clay-like soils. This is a problem during the rainy season in Japan in fields that have been converted from paddy fields. In 1970, the Japanese government introduced a policy to reduce the acreage under rice cultivation and promoted the conversion of paddy fields. Approximately $82.9 \%$ of the current domestic soybean cultivation occurs in such converted fields [2].

Converted fields generally produce high crop yields because of their fertile soil. However, paddy fields are designed to maintain wet conditions for rice production. Thus, the converted fields are prone to retain water because of their high water table and fine soil consisting of clay and silt particles. Therefore, crop production in converted fields can become unpredictable after heavy or prolonged rainfall. Technical modifications to minimize soil water fluctuations, such as high ridge cultivation [3] or inter-row strip-tillage [4], have been applied to avoid waterlogging injury. A new method to irrigate and drain soils was recently developed. The farm-oriented enhancing aquatic system uses underdrain and sub-irrigation systems to control the water table in converted fields and decrease water damage [5]. Although these modifications reduce the impact of water damage, waterlogging injury to crops produced in converted fields continues to be reported. Therefore, the development of waterlogging-tolerant soybean cultivars is still warranted.

For soybean cultivation in converted fields, excess water negatively affects germination and the subsequent post-emergence growth [6]. Waterlogging is associated with characteristic injuries. For example, during germination, rapid water uptake causes the seed structure to collapse [7] [8], while in plantlets, it interferes with physiological characteristics such as leaf water potential, nitrogen fixation, and mineral absorption [9] [10] [11]. However, soybean plantlets adapt to waterlogged soils by forming adventitious roots [12] [13] and secondary aerenchyma [14], as well as by undergoing other non-morphological changes to their root system. Although there is clear evidence of waterlogging tolerance in soybean plants, the mechanism underlying the development of waterlogging injury and tolerance has not been fully elucidated.

Information regarding variations in waterlogging tolerance among soybean cultivars is limited because of the poor reproducibility of the induced injuries. Many researchers have investigated the response of single cultivars to low-oxygen conditions or the phenotypic consequences of waterlogging stress across multiple cultivars [9] [12] [15] [16]. Although the use of a comparative physiological approach might provide new insights into soybean waterlogging tolerance, there are no available reports describing studies involving several cultivars under normal and oxygen-stress conditions in the root zone. The responses of eight Japanese soybean cultivars to hypoxic conditions were compared in a short-term hydroponic culture system [17] [18]. The results revealed a cultivar-specific waterlogging tolerance during the immature growth stage without the development of adventitious roots or aerenchyma. Additionally, some susceptible cultivars exhibited decreased shoot and root biomasses due to hypoxia, with some plants 
suddenly withering, possibly because of reduced root hydraulic conductance [18]. The present study involved a modified hydroponic culture system that enabled the creation of two different oxygen environments. Seedlings of nine soybean cultivars were grown in these hydroponic systems. Their responses to hypoxic conditions were determined by comparing shoot and root biomasses, hydraulic conductance, and root aquaporin-like protein production, which is related to root water permeability. This experimental design was used to clarify the mechanisms underlying the development of waterlogging injury in soybean plants.

\section{Materials and Methods}

\subsection{Plant Materials}

Most of the nine soybean [Glycine $\max$ (L.) Merr.] cultivars used in this study originated in Hokkaido (northern Japan) (Table 1). With the exception of "Suzumaru" ("SMa") and "Tanbakuro" ("TKu"), these cultivars have been used in studies of field waterlogging tolerance at the Hokkaido Central Agricultural Experiment Station (HCAES) and elsewhere [15] [17] [18] [19]. Some of the cultivars have exhibited unique waterlogging tolerance [15]. "Enrei" ("Ere"), which is widely grown in Japan, is insensitive to hypoxia, and has been used as a standard soybean cultivar [17]. "Toyomusume" ("TMu") seed responses to flooding and plant responses to hypoxia have been investigated [8] [18]. "Toyomusume" plants are insensitive to hypoxic [18] and waterlogged [20] conditions. "Shoku-kei32" ("S32") plants exhibit extreme field waterlogging tolerance [19] and hypoxia tolerance [18]. "Toyohomare" ("THo") plants are tolerant to flooding [20] and hypoxia [18], in contrast to "Toyoharuka" ("THa") plants [19]. "Suzumaru" plants produce extremely small seeds, and are thought to be susceptible to waterlogging stress. "Tanbakuro" plants, which are native to Hyogo prefecture,

Table 1. Field waterlogging tolerance and hypoxia tolerance of the nine analyzed soybean cultivars.

\begin{tabular}{|c|c|c|c|}
\hline Cultivar $^{a}$ & Abbreviation & $\begin{array}{l}\text { Field waterlogging } \\
\text { tolerance }\end{array}$ & Hypoxia tolerance $^{b}$ \\
\hline Enrei & ERe & Susceptible ${ }^{c}$ & Tolerant/Susceptible \\
\hline Koganejiro & $\mathrm{KJi}$ & Tolerant $^{d}$ & Enhanced/Tolerant \\
\hline Shoku-kei32 & S32 & Tolerant $^{e}$ & Enhanced/Tolerant \\
\hline Suzumaru & SMa & - & - \\
\hline Shirotsurunoko & STs & Susceptible ${ }^{d}$ & Susceptible \\
\hline Toyoharuka & THa & Susceptible ${ }^{e}$ & Susceptible \\
\hline Toyohomare & THo & Tolerant $^{e}$ & Tolerant \\
\hline Tanbakuro & $\mathrm{TKu}$ & - & - \\
\hline Toyomusume & $\mathrm{TMu}$ & Moderate $e^{e}$ & Tolerant \\
\hline
\end{tabular}

${ }^{a}$ Cultivars are arranged in alphabetical order (based on their abbreviations); ${ }^{b}$ Hypoxia tolerance of seven soybean cultivars was determined by Jitsuyama (2015) [18]. 'Jung et al. [52]; 'Matsukawa et al. [15]; ${ }^{e}$ HCAES [20]. 
produce large seeds surrounded by a black coat.

Before planting, all seeds were coated with the Cruiser MAXX ${ }^{\mathrm{ma}}$ fungicidal paste (22.6\% Thiamethoxam, Syngenta Japan K.K., Tokyo, Japan). This formulation provides seeds surface sterilization and protection against soybean diseases, including Phytophthora root and stem rot, which can occur following the development of waterlogging injury.

\subsection{Hydroponic Culture System}

Soybean seeds were germinated on wet paper towels in an EYELA MTI-202 incubator (Tokyo Rikakikai Co, Ltd., Tokyo, Japan) at $25^{\circ} \mathrm{C}$ in darkness [17] [18]. Soybean seedlings at the vegetative emergence growth stage (i.e., straight hypocotyl and unfolded cotyledons) were transferred to the hydroponic culture system in a separate LH-220S incubator (NK System Ltd., Osaka, Japan). Seedlings were maintained at a density of one plant per $20 \mathrm{~cm}^{2}$. The roots of 100 plantlets were immersed in a 10-L hydroponic solution [500-fold dilution of the Hyponica solution consisting of $80 \mathrm{mg} \cdot \mathrm{L}^{-1}$ nitrate, $76 \mathrm{mg} \cdot \mathrm{L}^{-1}$ phosphate, $178 \mathrm{mg} \cdot \mathrm{L}^{-1}$ potassium; Kyowa Co., Ltd., Osaka, Japan], while the stems were supported by a Bio-silico $\mathrm{N}$-type stopper (Hirschmann, Inc. Louisville, KY, USA) placed in the container lid holes. The plantlets were grown to the V2-V3 growth stages [21] without changing the hydroponic solution for 14 days.

To evaluate hypoxia tolerance, treated plantlets were maintained in a low-oxygen environment. After 2 weeks, growth under hypoxic and normal (aerobic) conditions was compared. In previous studies, an oxygen absorber was used to reduce oxygen levels [17] [18]. However, in the present study, nitrogen gas was used to maintain a stable hypoxic condition. The loading speed of the nitrogen gas was $0.05 \mathrm{~L} \cdot \mathrm{min}^{-1}$ per $10 \mathrm{~L}$ hydroponic solution. For the control treatment, the hydroponic solution was aerated using an air pump to achieve an oxygen concentration of $18.7 \%-19.0 \%$. The oxygen concentrations and temperatures of the hydroponic solutions for both treatment groups were monitored using DO METER ID-100 dissolved oxygen analyzers (Iijima Electronics Co., Aichi, Japan). The average oxygen concentrations under hypoxic and control conditions were $0.78 \pm 0.12 \mathrm{mg} \cdot \mathrm{L}^{-1}$ and $6.86 \pm 0.12 \mathrm{mg} \cdot \mathrm{L}^{-1}$, respectively. Thus, the oxygen concentrations were significantly different between the two treatments ( $p<0.001 ; \mathrm{n}=14$, Student's $t$-test). The air temperature of the incubator was $25^{\circ} \mathrm{C} \pm 0.05^{\circ} \mathrm{C}$, while the culture solution temperature was $22.1^{\circ} \mathrm{C} \pm 0.13^{\circ} \mathrm{C}$; there was no significant difference between the treatment groups $(p>0.1)$. During the experiment, the $\mathrm{pH}$ and electrical conductivity changed from 7.6 to 7.0 and from $1.36 \mathrm{mS} \cdot \mathrm{cm}^{-1}$ to $1.19 \mathrm{mS} \cdot \mathrm{cm}^{-1}$, respectively. No differences were observed between the two treatments regarding $\mathrm{pH}$ or electrical conductivity $(p>$ $0.1 ; \mathrm{n}=14$, Student's $t$-test). Thus, the two treatment groups differed only in plant materials, and samples were analyzed under equivalent conditions except for oxygen concentrations. Plants were grown under a 15.5-h photoperiod (light intensity: $190-200 \mu \mathrm{mol} \mathrm{m}^{-2} \cdot \mathrm{s}^{-1}$ ) in an incubator set at $25^{\circ} \mathrm{C}$ (dark period: $15^{\circ} \mathrm{C}$ ) and relative humidity of approximately $73 \%$. Each treatment group comprised 
10 plantlets per cultivar.

\subsection{Measurements}

Plants were harvested after a 14-day culturing period. The shoots were separated from the roots, and the leaves were collected. The leaf area was then measured using an AAM-7 automated area meter (Hayashi Denko Co. Ltd., Tokyo, Japan). Measurements were completed using three plants (i.e., one plant per replicate).

Roots were carefully removed from the hydroponic solution, after which their hydraulic conductance (i.e., inverse of hydraulic resistivity) was measured according to a pressure chamber method [22]. A pressure chamber was prepared using a pump-up chamber (PMS Instrument Company, Albany, OR, USA) and an AM02-04N air compressor (Fujiwara Sangyo Co., Ltd., Hyogo, Japan) to automatically pressurize the chamber [8]. A root was fixed to the lid of a pressure chamber and the root system was immersed in the hydroponic solution. The internal pressure of the chamber was increased step-wise by $50 \mathrm{kPa}$ at 30 -s intervals up to $600 \mathrm{kPa}(0.6 \mathrm{MPa})$. The water discharged through the roots was trapped every $30 \mathrm{~s}$ using a pre-weighed cotton swab. The cotton swab was weighed before and after use with a VIC212 electric balance (sensitivity: $1 \mathrm{mg}$ ) (ACCULAB Sartorius AG, Göttingen, Germany). Hydraulic conductance was estimated as a "flow ratio" [i.e., water volume per unit time and root length $\left(\mu \mathrm{L} \cdot \mathrm{m}^{-1} \cdot \mathrm{min}^{-1}\right)$. The relationship between hydraulic conductance and loading pressure was determined. The linear increase in hydraulic conductance was defined as the index of root hydraulic conductivity [i.e., $\mathrm{Lp}\left(\mu \mathrm{L} \cdot \mathrm{MPa}^{-1} \cdot \mathrm{m}^{-1} \cdot \mathrm{min}^{-1}\right)$ ], which is represented by the slope of the linear phase of the curve [23]. Measurements were completed with three plants (i.e., the roots of one plant per replicate).

The roots were rinsed gently with tap water, after which various root morphological characteristics were analyzed using WinRhizo (Regent Instruments Inc., Canada; Supplementary Figure 1(A)-(D)). Roots with a diameter of $0.4-0.7 \mathrm{~mm}$ were designated "thick roots", while those with a diameter smaller than $0.4 \mathrm{~mm}$ were defined as "fine roots" (Supplementary Figure 1(E)). The analyses were completed with three plants (i.e., the roots of one plant per replicate). Thus, three plants from each cultivar were used for leaf area, root conductivity, and root morphology measurements. Additionally, four plants from each cultivar were separated into leaves, stems, and roots. The plant tissue samples were dried at $80^{\circ} \mathrm{C}$ for 3 days, after which the dry mass of each organ from each plant was measured.

The H/A ratio, which represents the effect of hypoxic $(\mathrm{H})$ and aerobic (A) conditions on plant biomass, was used to evaluate plant responses to hypoxia. An H/A ratio greater than 1.0 indicated that the trait was enhanced by hypoxia (i.e., the cultivar is tolerant), and a ratio less than 1.0 indicated that the cultivar was damaged by hypoxia (i.e., the cultivar is sensitive). Ratios close to 1.0 suggested that hypoxic conditions had limited effects on plants.

\subsection{Protein Extraction and Immunoblotting Analysis}

Proteins (including aquaporins) were extracted from plant tissues essentially as 
described by Hanba et al. [24]. Frozen soybean roots (approximately $0.3 \mathrm{~g} \mathrm{FW}$ ) from plants in the two treatment groups were ground to a powder in liquid nitrogen and placed in $0.9 \mathrm{~mL}$ extraction buffer [50 mM Tris- $\mathrm{HCl}(\mathrm{pH} 7.8), 0.3 \mathrm{M}$ sucrose, $8 \mathrm{mM}$ ethylenediamine tetraacetic acid, $4 \mathrm{mM}$ dithiothreitol, and $2 \mathrm{mM}$ phenylmethylsulfonyl fluoride] at $4^{\circ} \mathrm{C}$. Samples were centrifuged at $10,000 \mathrm{rpm}$ for $10 \mathrm{~min}$ at $4^{\circ} \mathrm{C}$. A $100-\mu \mathrm{L}$ aliquot of the supernatant was diluted with $100 \mu \mathrm{L}$ Laemmli's buffer [500 mM Tris- $\mathrm{HCl}(\mathrm{pH} 6.8), 3 \%$ (w/w) sodium dodecyl sulphate (SDS), $30 \%(\mathrm{w} / \mathrm{v})$ glycerol, $9.3 \%(\mathrm{w} / \mathrm{w})$ dithiothreitol, and $1.2 \%(\mathrm{w} / \mathrm{w})$ bromophenol blue] and then heated at $70^{\circ} \mathrm{C}$ for $10 \mathrm{~min}$. The solution was used as a soluble protein fraction, and its protein content was determined using the Bradford assay [25]. Proteins were separated by one-dimensional SDS-polyacrylamide gel electrophoresis (PAGE) [26] using $5.1 \mu$ g protein per lane. The SDS-PAGE was conducted with a $4 \%$ stacking gel and a $12.5 \%$ running gel at a constant current of $20.5 \mathrm{~mA}$. The proteins were then electrotransferred to an AE-6668 polyvinylidene difluoride membrane (ATTO Co., Tokyo, Japan) for $30 \mathrm{~min}$ at 80 $\mathrm{mA}$ in a transfer solution [25 $\mathrm{mM}$ Tris base and $5 \%(\mathrm{v} / \mathrm{v})$ methanol]. The proteins were probed with the following four rabbit polyclonal anti-aquaporin antibodies (1:1000 dilution; Cosmo Bio Co., Ltd., Tokyo, Japan): anti-PIP1s (PIP1;1, 1; 2, and 1; 3; epitope: KDYNEPPPAPLFEPGELSSWS-C), anti-PIP2s (PIP2;1, 2;2, and 2; 3; epitope: Cys-QFVLRASGSKSLGSFRSA), anti-TIP1s gamma (TIP1;1 and TIP1; 2; epitope: GVQEEVTHPSALRA-Cys), and anti-TIP2;1 delta (epitope: Cys-MTSEHVPLASEF). Antibodies were visualized using an alkaline phosphatase-conjugated goat anti-rabbit IgG secondary antibody (1:500 dilution; Bio-Rad Laboratories Inc., CA, USA) and an AP Conjugate Substrate Kit, which included a 5-bromo-4-chloro-3-indolyl phosphate/nitroblue tetrazolium reagent system (Bio-Rad Laboratories Inc.). Because the density of the resulting bands was insufficient for photographs, membranes were scanned and analysed using the UN-SCAN-IT gel image analysis software (Silk Scientific, Inc., UT, USA). The protein quantifications were repeated three times (i.e., one frozen root sample per replicate) for each cultivar. The densities of the detected bands were converted to values that represented the relative protein abundance. These values were then compared among cultivars and treatments. Some partial SDS-PAGE gels were stained with Coomassie brilliant blue, and the location of specific bands was determined immunologically.

\subsection{Statistical Analysis}

One plantlet was defined as a replicate, and three or four replicates were analyzed using a randomized block design. A two-way analysis of variance was used to compare the average values of all plant biomass data among treatments (i.e., aerobic vs hypoxic conditions) and cultivars. Additional statistical analyses included the Tukey-Kramer and Student's $t$-test, which were used to separate means, and Pearson's correlation analysis, which was used to determine the relationship between two traits. Data analyses were conducted using SPSS 20.0 (IBM Corp., Armonk, NY, USA). 


\section{Results}

\subsection{Effect of Hypoxia on Soybean Biomass}

The dry weight data for leaves, stems, and roots for each cultivar under the two treatment conditions are summarized in Table 2. The leaves and roots were the heaviest and lightest parts of the soybean plants, respectively. The hypoxic treatment significantly decreased the average stem dry weight $(p<0.05)$. Among the nine cultivars, "TKu" and "SMa" had the largest and smallest biomasses, respectively (Table 2). The cultivars with the largest leaf biomass were "TKu", "Shirotsurunoko" ("STs"), and "TMu". "Koganejiro" ("KJi”) plants produced the largest root biomass. Although there were significant differences in biomass for the different components among the cultivars $(p<0.001)$, significant interactions between treatment and cultivar $(p<0.05-0.001)$ were also detected for all plant components. These results indicated that the effects of hypoxia on biomass differed among the cultivars (Table 2). A comparison of the mean square values revealed they were generally higher among cultivars (C) than between treatments $(\mathrm{T})$ or for the interaction $(\mathrm{C} \times \mathrm{T})$. However, for root dry matter, the mean square value for the interaction was higher than that between treatments or among cultivars. This suggests that the effect of hypoxia was different among cultivars regarding root biomass. Because the effect was significant, the characteristics of each cultivar were examined separately in the following analysis.

Table 2. Average dry weights of leaves, stems, and roots. Analysis of variance was used to compare the variables among cultivars under different conditions.

\begin{tabular}{|c|c|c|c|c|c|c|c|c|c|c|c|c|c|}
\hline & & \multicolumn{3}{|c|}{ Leaf dry weight (mg) } & \multicolumn{3}{|c|}{ Stem dry weight (mg) } & \multicolumn{3}{|c|}{ Root dry weight (mg) } & \multicolumn{3}{|c|}{ Total dry weight (mg) } \\
\hline \multicolumn{2}{|l|}{ Average } & \multirow{2}{*}{$\begin{array}{l}252.6 \\
300.5\end{array}$} & \multicolumn{2}{|l|}{$(17.0)^{a}$} & \multirow{2}{*}{$\begin{array}{l}179.0 \\
225.3\end{array}$} & \multicolumn{2}{|l|}{$(15.7)$} & \multirow{2}{*}{$\begin{array}{l}88.8 \\
105.8\end{array}$} & \multicolumn{2}{|l|}{ (6.7) } & \multirow{2}{*}{$\begin{array}{l}519.9 \\
631.5\end{array}$} & \multicolumn{2}{|l|}{$(32.7)$} \\
\hline Treatment & Aerobic & & $(24.4)$ & & & $(23.8)$ & & & $(7.4)$ & & & $(47.4)$ & \\
\hline & Hypoxic & 204.6 & $(21.1)$ & & 132.8 & $(17.8)$ & & 71.8 & $(10.5)$ & & 408.2 & $(36.9)$ & \\
\hline \multirow{9}{*}{$\begin{array}{l}\text { Cultivar } \\
\text { (C) }\end{array}$} & $\mathrm{ERe}$ & 146.7 & $(14.6)$ & $\mathrm{bc} c^{b}$ & 136.6 & $(32.9)$ & $\mathrm{bc}$ & 51.5 & $(15.0)$ & $\mathrm{b}$ & 330.6 & $(61.6)$ & $\mathrm{cd}$ \\
\hline & $\mathrm{KJi}$ & 249.9 & (18.9) & $\mathrm{ab}$ & 205.9 & $(36.5)$ & $a b c$ & 146.2 & $(29.3)$ & a & 601.9 & $(49.8)$ & $a b c$ \\
\hline & S32 & 239.2 & $(44.7)$ & $\mathrm{ab}$ & 121.8 & $(21.3)$ & $\mathrm{bc}$ & 72.3 & (7.5) & $\mathrm{ab}$ & 433.3 & $(43.4)$ & bcd \\
\hline & $\mathrm{SMa}$ & 53.3 & $(20.9)$ & c & 65.5 & (18.5) & c & 50.5 & (3.7) & b & 169.3 & $(32.5)$ & $\mathrm{d}$ \\
\hline & STs & 337.7 & $(46.5)$ & $\mathrm{a}$ & 247.6 & $(38.4)$ & $\mathrm{ab}$ & 110.0 & $(21.6)$ & $\mathrm{ab}$ & 695.3 & $(97.2)$ & $\mathrm{ab}$ \\
\hline & $\mathrm{THa}$ & 295.9 & $(48.4)$ & $\mathrm{ab}$ & 144.9 & $(37.8)$ & $\mathrm{bc}$ & 90.8 & $(22.3)$ & $\mathrm{ab}$ & 531.1 & (103.5) & $a b c$ \\
\hline & THo & 240.4 & $(45.7)$ & $\mathrm{ab}$ & 107.8 & $(36.9)$ & $\mathrm{bc}$ & 74.3 & $(13.1)$ & $a b$ & 422.2 & $(61.7)$ & $\mathrm{bcd}$ \\
\hline & $\mathrm{TKu}$ & 340.9 & $(67.8)$ & $\mathrm{a}$ & 354.5 & (71.9) & $\mathrm{a}$ & 96.2 & $(26.5)$ & $\mathrm{ab}$ & 791.6 & (133.6) & $\mathrm{a}$ \\
\hline & $\mathrm{TMu}$ & 369.3 & $(22.0)$ & $\mathrm{a}$ & 226.6 & $(31.4)$ & $a b c$ & 107.8 & (7.5) & $\mathrm{ab}$ & 703.6 & $(22.4)$ & $\mathrm{ab}$ \\
\hline ANOVA & $\mathrm{df}$ & MS & & $\operatorname{Sig}^{c}$ & MS & & Sig & MS & & Sig & MS & & Sig \\
\hline $\mathrm{T}$ & 1 & 45733 & & ns & 27968 & & * & 485 & & ns & 12757 & & ns \\
\hline C & 8 & 81811 & & $* * *$ & 62679 & & $* * *$ & 7495 & & $* * *$ & 320977 & & $* * *$ \\
\hline $\mathrm{T} \times \mathrm{C}$ & 8 & 56327 & & $* * *$ & 16606 & & * & 12352 & & $* * *$ & 172607 & & $* * *$ \\
\hline
\end{tabular}

The mean square and significance values are provided; ${ }^{a}$ Values in parentheses denote standard error; ${ }^{b}$ Different letters within each row indicate significant differences at the 0.05 probability level according to the Tukey-Kramer test $(\mathrm{n}=8) .{ }^{c *}$ and ${ }^{\star * \star}$ in each row represent significance at 0.05 and 0.001 probability levels, respectively; ns, not significant according to ANOVA $(n=4)$; ANOVA, analysis of variance; df, degree of freedom; MS, mean square; Sig., significance. 
Leaf, stem, root, and total dry weights were compared between the two treatment groups for each cultivar (Table 3$)$. The leaf dry weights of "Ere" $(p<0.01)$, "SMa" $(p<0.01)$, “STs" $(p<0.01)$, “THa" $(p<0.01)$, “THo" $(p<0.001)$, and "TKu" $(p<0.01)$ plants were significantly decreased by hypoxia, whereas that of "S32" plants was significantly increased $(p<0.001)$. The stem dry weights of "Ere" and "THa" plants were significantly decreased by hypoxia $(p<0.001)$. Additionally, the root dry weights of "Ere" $(p<0.001)$, "STs" $(p<0.01)$, "THa" $(p<0.001)$, and "TKu" plants $(p<0.01)$ were significantly decreased by hypoxia, whereas that of "KJi" plants was increased $(p<0.05)$. The total dry weights of the cultivars decreased under hypoxic conditions in the order "Ere" $(p<0.001)$, "SMa" $(p<0.01)$, "STs" $(p<0.01)$, “THa" $(p<0.001)$, “THo" $(p<0.05)$, and "TKu” $(p<0.001)$. In contrast, the dry weight of "S32" plants increased after the hypoxia treatment (Table 3). The H/A values were used to estimate the waterlogging tolerance of each cultivar. The "S32" and "KJi" plants exhibited waterlogging tolerance, and tended to have high $\mathrm{H} / \mathrm{A}$ ratios for each biomass.

\subsection{Changes in Root Hydraulic Conductivity Due to Hypoxia}

The flow ratio (per total root length, per minute) of sap solution from cut stems after roots were pressurized was plotted for each cultivar and treatment. The analyses revealed differences in loading pressures among cultivars (Figure 1). An increase in pressure resulted in increased sap production for all cultivars.

Table 3. Leaf, stem, root, and total dry weights as well as the ratio between hypoxic $(\mathrm{H})$ and aerobic (A) conditions for each cultivar.

\begin{tabular}{|c|c|c|c|}
\hline \multirow{2}{*}{ Cultivar } & \multicolumn{3}{|c|}{ Leaf dry weight (mg) } \\
\hline & A & $\mathrm{H}$ & $\mathrm{H} / \mathrm{A}$ \\
\hline \multirow{2}{*}{$\mathrm{ERe}$} & 180.0 & 113.3 & \multirow{2}{*}{0.63} \\
\hline & \multicolumn{2}{|c|}{${ }^{* *} \nabla$} & \\
\hline \multirow{2}{*}{$\mathrm{KJi}$} & 222.5 & 277.3 & \multirow{2}{*}{1.25} \\
\hline & \multicolumn{2}{|c|}{ ns } & \\
\hline \multirow{2}{*}{ S32 } & 128.0 & 350.3 & \multirow{2}{*}{2.74} \\
\hline & \multicolumn{2}{|c|}{$* * * \boldsymbol{\Lambda}$} & \\
\hline \multirow{2}{*}{ SMa } & 104.0 & 2.6 & \multirow{2}{*}{0.03} \\
\hline & \multicolumn{2}{|c|}{${ }^{* *} \nabla$} & \\
\hline \multirow{2}{*}{ STs } & 441.0 & 234.3 & \multirow{2}{*}{0.53} \\
\hline & & & \\
\hline \multirow{2}{*}{ THa } & 407.3 & 184.6 & \multirow{2}{*}{0.45} \\
\hline & & & \\
\hline \multirow{2}{*}{ THo } & 357.8 & 123.1 & \multirow{2}{*}{0.34} \\
\hline & & & \\
\hline \multirow{2}{*}{$\mathrm{TKu}$} & 493.8 & 188.1 & \multirow{2}{*}{0.38} \\
\hline & & & \\
\hline \multirow{2}{*}{$\mathrm{TMu}$} & 370.3 & 368.3 & \multirow{2}{*}{0.99} \\
\hline & & & \\
\hline
\end{tabular}

\begin{tabular}{|c|c|c|}
\hline \multicolumn{3}{|c|}{ Stem dry weight (mg) } \\
\hline A & $\mathrm{H}$ & $\mathrm{H} / \mathrm{A}$ \\
\hline 219.6 & 53.6 & \\
\hline \multicolumn{2}{|c|}{$* * * \nabla$} & \\
\hline 207.8 & 203.9 & 0.98 \\
\hline \multicolumn{2}{|c|}{ ns } & \\
\hline 160.7 & 83.0 & \\
\hline \multicolumn{2}{|c|}{$\dagger$} & 0.52 \\
\hline 94.6 & 36.4 & 038 \\
\hline \multicolumn{2}{|c|}{ ns } & \\
\hline 315.8 & 179.4 & 057 \\
\hline \multicolumn{2}{|c|}{$\dagger$} & \\
\hline 240.9 & 49.0 & \\
\hline \multicolumn{2}{|c|}{$* * * \nabla$} & \\
\hline 88.0 & 127.6 & \\
\hline \multicolumn{2}{|c|}{ ns } & 1.40 \\
\hline 465.5 & 243.6 & 052 \\
\hline \multicolumn{2}{|c|}{ ns } & 0.02 \\
\hline 234.8 & 218.3 & 093 \\
\hline
\end{tabular}

\begin{tabular}{|c|c|c|}
\hline \multicolumn{3}{|c|}{ Root dry weight (mg) } \\
\hline A & $\mathrm{H}$ & $\mathrm{H} / \mathrm{A}$ \\
\hline \multirow[t]{2}{*}{90.3} & 12.8 & \\
\hline & & \\
\hline \multirow[t]{2}{*}{89.0} & 203.3 & \\
\hline & & 2.20 \\
\hline \multirow[t]{2}{*}{61.3} & 83.3 & \\
\hline & & \\
\hline \multirow[t]{2}{*}{50.3} & 50.8 & \\
\hline & & \\
\hline \multirow[t]{2}{*}{158.0} & 62.1 & \\
\hline & & \\
\hline \multirow[t]{2}{*}{147.8} & 33.8 & 023 \\
\hline & & \\
\hline \multirow[t]{2}{*}{93.0} & 55.6 & \\
\hline & & 0.00 \\
\hline \multirow[t]{2}{*}{160.5} & 31.8 & \\
\hline & & 0.20 \\
\hline 102.5 & 113.1 & 1.10 \\
\hline
\end{tabular}

\begin{tabular}{|c|c|c|}
\hline \multicolumn{3}{|c|}{ Total dry weight $(\mathrm{mg})$} \\
\hline A & $\mathrm{H}$ & $\mathrm{H} / \mathrm{A}$ \\
\hline 489.9 & 171.3 & \multirow{2}{*}{0.34} \\
\hline \multicolumn{2}{|c|}{${ }^{* * *} \nabla$} & \\
\hline 519.3 & 684.5 & \\
\hline \multicolumn{2}{|c|}{$\dagger$} & \\
\hline 349.9 & 516.6 & \\
\hline \multicolumn{2}{|c|}{${ }^{*} \boldsymbol{\Delta}$} & 1.70 \\
\hline 248.9 & 89.8 & \\
\hline \multicolumn{2}{|c|}{$* * \nabla$} & \\
\hline 914.8 & 475.8 & \\
\hline \multicolumn{2}{|c|}{$* * \nabla$} & 0.00 \\
\hline 795.9 & 266.4 & \\
\hline \multicolumn{2}{|c|}{${ }^{* * *} \nabla$} & 0.35 \\
\hline 538.1 & 306.2 & \\
\hline \multicolumn{2}{|c|}{${ }^{*} \nabla$} & 0.37 \\
\hline 1119.7 & 463.5 & \\
\hline \multicolumn{2}{|c|}{$* * * \nabla$} & 0.41 \\
\hline 707.6 & 699.7 & 099 \\
\hline
\end{tabular}

$\dagger^{*}, *^{* *}$, and ${ }^{* * *}$ represent significance at $0.1,0.05,0.01$, and 0.001 probability levels, respectively; ns, not significant according to Student's $t$-test $(\mathrm{n}=4)$. and $\nabla$ indicate significant increases and decreases in dry weight, respectively. 
There was a significant variation in the linear part of the curves representing responses to hypoxia among cultivars. The "SMa", "STs", "THa", and "TKu" cultivars exhibited a significant decrease in the flow ratio in response to hypoxic conditions, whereas the opposite trend was observed for "S32" and "THo" cultivars.

The variation in the linear range of increasing flow was calculated and defined as the hydraulic root conductivity [i.e., $\mathrm{Lp}\left(\mu \mathrm{L} \cdot \mathrm{MPa}^{-1} \cdot \mathrm{m}^{-1} \cdot \mathrm{min}^{-1}\right)$ ]. Higher Lp values corresponded to greater root permeability per unit length. The H/A ratiofor the Lp values are indicated as an italicized number after the abbreviated cultivar names in Figure 1. If the Lp value under aerobic conditions decreased relative to that of the hypoxia treatment, the H/A ratio for the Lp value also decreased, indicating limited hydraulic conductivity due to hypoxia.

To identify the morphological characteristics that responded to hypoxic conditions similarly to hydraulic root conductivity, the correlation coefficients between root hydraulic conductivity and the other analysed characteristics were determined (Table 4). The H/A ratios for the total dry weights of hypoxia-treated and control plants were positively related $(\mathrm{r}=0.78 ; p<0.05)$ to the corresponding ratio for root hydraulic conductivity. This was also true for the leaf dry weight $\mathrm{H} / \mathrm{A}$ ratio $(\mathrm{r}=0.85 ; p<0.01)$. This positive relationship was attributed to leaf area $(\mathrm{r}=0.89 ; p<0.01)$ rather than leaf thickness $(\mathrm{r}=0.09 ; p>$ 0.1 ) (Table 4, Figure 2(A)). Although there was no correlation between the H/A ratios for root dry weight and root conductivity, the $\mathrm{H} / \mathrm{A}$ ratios for root length ( $\mathrm{r}$ $=0.67 ; p<0.05)$ [especially thick-root length $(\mathrm{r}=0.73 ; p<0.05)$ (Figure 2(B))] and number of root tips $(\mathrm{r}=0.68 ; p<0.05)$ (Figure $2(\mathrm{C})$ ) were significantly correlated with the H/A ratio for root conductivity (Table 4).

\subsection{Changes in Root Aquaporin-Like Proteins Due to Hypoxia}

The preceding sections have described the effects of morphological characteristics on root hydraulic conductivity. To assess the effects of non-morphological characteristics on root hydraulic conductivity, the hypoxia-induced responses of water channels, which are related to root water permeability, were examined. Digital image analyses of SDS-PAGE gels stained with Coomassie brilliant blue indicated that band densities were not significantly influenced by exposures to hypoxic conditions for all cultivars (data not shown).

An immunoblot analysis revealed variations in the abundance of root aquaporin-like proteins in hypoxia-treated plants. Although four different polyclonal anti-aquaporin antibodies were used, bands were only detected by the anti-PIP1s antibody. This antibody generated five different bands (i.e., 24.3, 27.1, 32.3, 41.3 - 50.8, and $67.7-108.5 \mathrm{kDa}$ ), which were presumably derived from a single band or a group of bands (Figure 3 ).

The intensity of the $24.3 \mathrm{kDa}$ band representing PIP1s-like proteins differed significantly between treatments and cultivars $(p<0.01$; Supplementary Table 1 ). The intensity of the $24.3 \mathrm{kDa}$ band decreased significantly for the "Ere" ( $p$ $<0.05)$, "SMa" $(p<0.01)$, and "THo" $(p<0.05)$ cultivars exposed to hypoxic conditions. In contrast, the intensity of this protein band increased considerably 


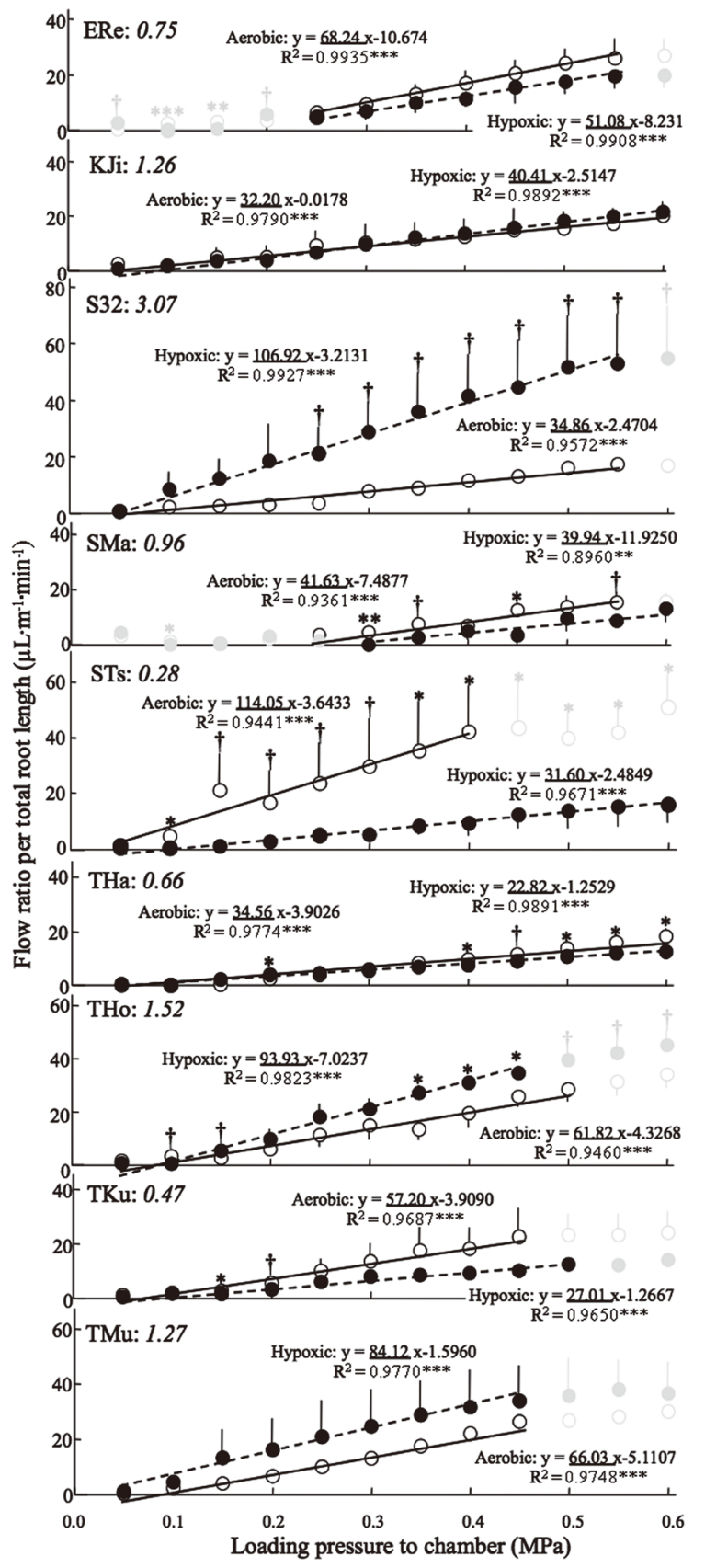

Figure 1. Relationship between the loading pressure of the chamber and the flow ratio per root length, which corresponds to the root hydraulic conductivity (Lp: $\mu \mathrm{L} \mathrm{MPa}^{-1} \mathrm{~m}^{-1}$ $\left.\min ^{-1}\right)$. Data are provided as the means from three replicates, and bars indicate standard errors. $\dagger,{ }^{*}$, and ${ }^{* *}$ represent significant differences between the control (open circles) and hypoxia-treated (closed circles) samples at $0.1,0.05$, and 0.01 probability levels, respectively, according to Student's $t$-test. The regression lines were associated with formulae ( ${ }^{\star *}$ and ${ }^{\star * *}$ represent significance at the 0.01 and 0.001 probability levels, respectively) with correlation coefficients based on Pearson's correlation analysis. The formula for each regression line is as follows: Treatment: $\mathrm{y}=\mathrm{a} \times \mathrm{x}+\mathrm{b}$; where $\mathrm{a}=\mathrm{Lp}$ and $\mathrm{b}=$ constant. The Lp value is defined by the slope of the linear phase of the curve (Emery and Salon 2002) [23]. The values indicated by half tone symbols were not used for calculating the regression line because they were not included in the linear relationship between the loading pressure and flow ratio per total root length. The values in italics next to the abbreviated cultivar names indicate the Lp value ratios between hypoxic and aerobic conditions. 
Table 4. Significance of the correlation coefficient for the relationship between the hypoxic $(\mathrm{H}) /$ aerobic $(\mathrm{A})$ ratio of root hydraulic conductivity and the H/A ratio of various characteristics.

\begin{tabular}{lll}
\hline Characteristic & $\mathrm{r}$ & Sig. $^{a}$ \\
\hline Dry weights & & $* *$ \\
Leaf & 0.8467 & $\mathrm{~ns}$ \\
Stem & 0.2643 & $\mathrm{~ns}$ \\
Root & 0.5275 & $*$ \\
Total & 0.7791 & \\
\hline Leaf traits & & $* *$ \\
Area & 0.8856 & $\mathrm{~ns}$ \\
Thickness & 0.0899 & \\
Root traits & & $\mathrm{ns}$ \\
Average diameter & 0.3120 & $*$ \\
Number of tips & 0.6864 & $*$ \\
Total length & 0.6678 & $*$ \\
Thick-root length & \\
Fine-root length & & \\
\end{tabular}

${ }^{a}$ and ${ }^{* \star}$ represent significance at 0.05 and 0.01 probability levels, respectively; ns, not significant according to Pearson's correlation analysis; ${ }^{b}$ Thick and fine roots were defined as those having a diameter of $0.4-0.7$ $\mathrm{mm}$ and $0.0-0.4 \mathrm{~mm}$, respectively; r, correlation coefficient; Sig., significance.
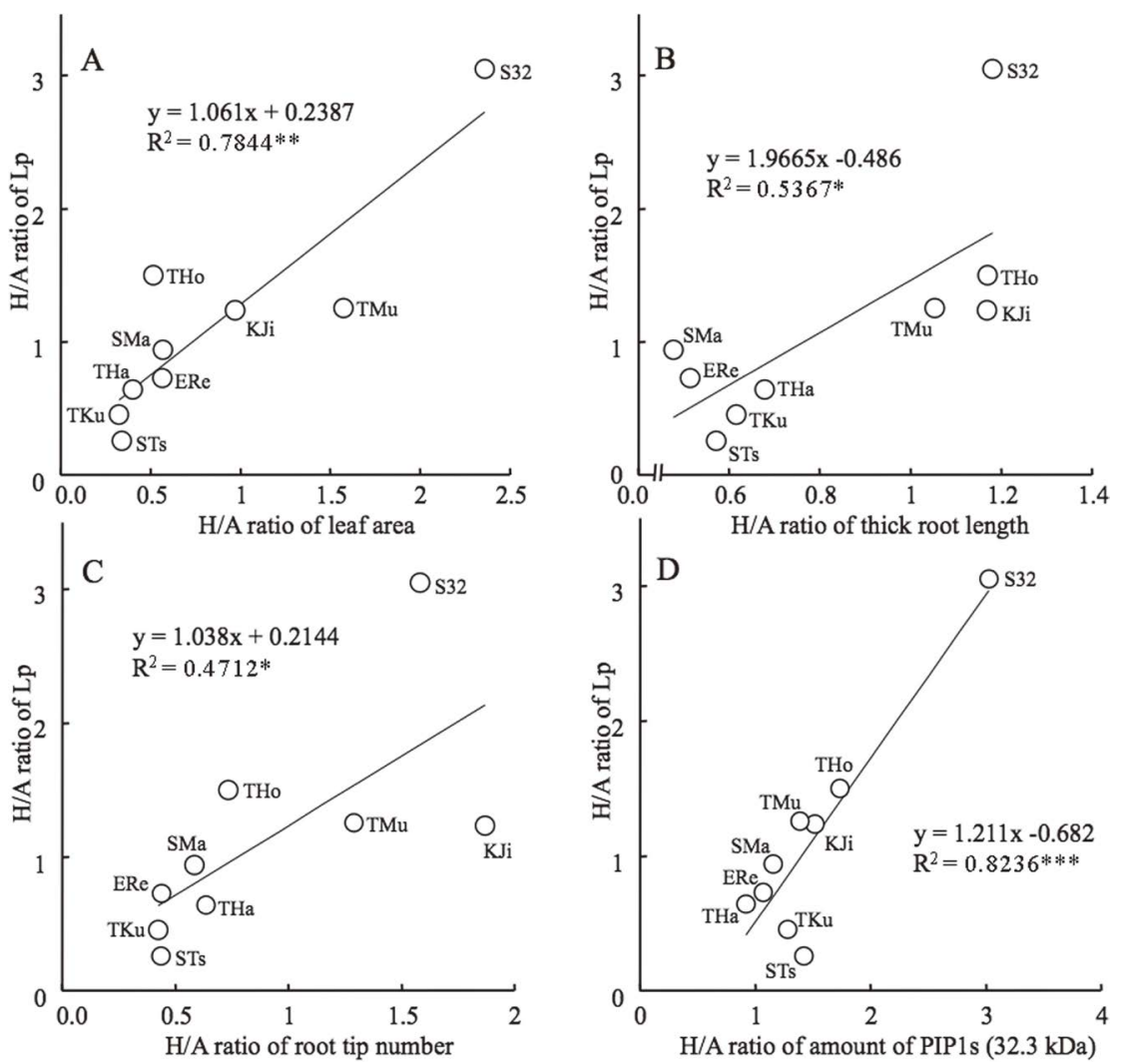

Figure 2. Relationships between the hypoxic (H)/aerobic (A) ratio of root hydraulic conductivity (Lp) and the H/A ratios of leaf area (A), thick-root length (B), number of root tips (C), and abundance of PIP1s $(32.3 \mathrm{kDa})(\mathrm{D})$. Abbreviated cultivar names accompany each symbol. Regression lines marked by ${ }^{*},{ }^{* *}$, and ${ }^{* *}$ indicate significance at the $0.05,0.01$, and 0.001 probability levels, respectively, according to Pearson's correlation analysis $(n=9)$. 


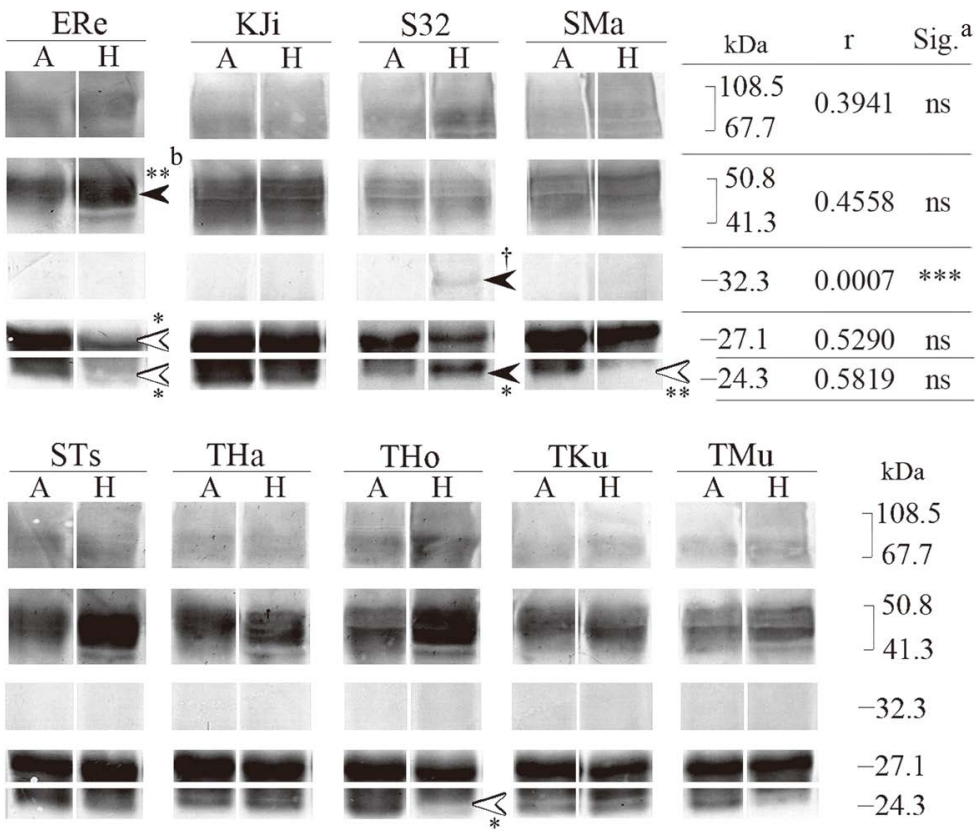

Figure 3. Immunoblot analysis of soluble proteins extracted from soybean roots, and the correlation coefficient ( $\mathrm{r}$ ) and significance (Sig.) of the relationship between the hypoxic $(\mathrm{H}) /$ aerobic $(\mathrm{A})$ ratio of root hydraulic conductivity $(\mathrm{Lp})$ and the H/A ratio of protein abundance. An anti-aquaporin (PIP 1;1, 1;2, and 1;3) antibody was used. Closed and open arrowheads indicate proteins whose abundance significantly increased and decreased, respectively, under hypoxic conditions in a hydroponic culture. Each lane contained $5.1 \mu \mathrm{g}$ total protein. $\mathrm{a}^{\star * \star}$ represents significance at the 0.001 probability level, while ns means not significant according to Pearson's correlation analysis $(\mathrm{n}=9) . \mathrm{b} \dagger,{ }^{\star}$, and ${ }^{\star \star}$ above arrowheads represent significant differences in the band densities between the control and hypoxia-treated samples at $0.1,0.05$, and 0.01 probability levels, respectively, according to Student's $t$-test.

for the "S32" plants under the same conditions ( $p<0.05$; Figure 3 ). For the "Ere" plants under hypoxic conditions, the intensity of the $27.1 \mathrm{kDa}$ band decreased and that of the $41.3-50.8 \mathrm{kDa}$ bands increased. There were no differences in the intensities of the 67.7 - $108.5 \mathrm{kDa}$ bands between treatments for any cultivar.

The relationship between the $\mathrm{H} / \mathrm{A}$ ratio for root hydraulic conductivity and the H/A ratio for PIP1s band sizes in the two treatments was analyzed (Figure 3 ). The interaction between the $\mathrm{H} / \mathrm{A}$ ratios was significant for only the $32.3 \mathrm{kDa}$ band $(p<0.001)$. Furthermore, the relationship was positive (Figure $2(\mathrm{D})$ ), implying that the increase in the abundance of the aquaporin-like protein enhanced root hydraulic conductivity.

\section{Discussion}

\subsection{Analysis of the Mechanism Underlying Field Waterlogging Tolerance Based on Responses to Hypoxic Conditions}

The main cause of waterlogging injury in soybean plants is reportedly the low respiration levels in the roots because of a lack of oxygen in the rhizosphere. This in turn limits nutrient uptake and eventually decreases photosynthetic activities [27]. Soybean plantlets require more oxygen than other field crops be- 
cause the nitrogen-fixing bacteria in their root nodules need a considerable oxygen supply. Because the nitrogen supply from nodules is substantially reduced at lower partial pressures of oxygen, rhizospheric hypoxia is a primary factor triggering waterlogging injury in field crops [28]. The present study involved a hydroponic culture system to avoid having to consider the effects of nodule bacteria. Additionally, the duration of the experiment was insufficient for the hypoxia treatment to induce the formation of aerenchymatous cells, as reported by Thomas et al. [16] and Shimamura et al. [14]. Therefore, the observed responses of immature soybean plantlets to hypoxic conditions were unaffected by nodulation or the aerenchyma.

Hypoxia significantly influenced all biomass traits investigated in this study. The degree of influence varied significantly among different cultivars. Thus, the cultivars could be categorized according to their specific hypoxic responses (Table 3). The nine cultivars were grouped into the following three hypoxic-response categories: cultivars exhibiting stimulated growth (enhanced type: "S32" and "KJi"), those unaffected by hypoxia (tolerant type: "THo" and "TMu"), and those exhibiting decreased growth (susceptible type: "Ere", "SMa", "STs", "THa", and "TKu"). The oxygen diffusion rate in the soil is closely related to the rate of plant root development [29]. This characteristic might also apply to the hypoxic responses of the susceptible cultivars examined in the present study. Thus, cultivar-specific hypoxic effects may be associated with the soybean waterlogging response. Some researchers have indicated that high carbon dioxide levels [30] [31] [32] or impaired mineral diffusion [33] in the rhizosphere are key factors influencing crop waterlogging injury. Additionally, low partial pressure of oxygen around the roots [17] [34] should be considered an important factor in the development of waterlogging injury in soybean plants.

\subsection{Cultivar-Specific Response to Hypoxia Related to Root Hydraulic Conductivity}

Plants that have been exposed to anoxic conditions exhibit decreased respiratory activities and impaired mitochondrial functions [35]. Growth rates and yields have been reported to decrease in these plants because of limited water and nutrient uptake [36]. The cultivation of soybean in wet soil inhibits root development and nodulation [37], ultimately resulting in low yields [1]. The hypoxic conditions used in the present study tended to decrease plant biomass and shrink the root system of susceptible cultivars. In addition to light, a suitable temperature, and carbon dioxide, plants depend on water and nutrients for growth. In our experimental environments, all soybean plantlets were exposed to the same light conditions, temperatures, and carbon dioxide levels. Although both treatment groups were supplied with equal amounts of water, plant water usage may have differed depending on the plant status under specific conditions. The differences in growth and biomass due to hypoxia treatments implied that water usage is likely a key factor affecting the development of waterlogging injury. 
The analysis of the effects of hypoxia on root water permeability using the pressure chamber method revealed that the level of hypoxia required to affect the sap flow ratio for cut stems with pressurized roots differed significantly among cultivars. These results suggest that hypoxia affected root hydraulic conductivity in specific cultivars. In "S32", "THo", "KJi", and "TMu" plants, the $\mathrm{H} / \mathrm{A}$ ratio of Lp was greater than 1.0, indicating that root water permeability was enhanced by hypoxia. In contrast, the H/A ratio of Lp for "Ere", "SMa", "STs", "THa", and "TKu" plants was less than 1.0, indicating that the root water permeability for these cultivars decreased in response to hypoxia. This separation of cultivars based on differences in root hydraulic conductivity under hypoxic conditions suggests a close relationship between this response and hypoxia tolerance.

\subsection{Root Hydraulic Conductivity Fluctuates with Changes to Leaf and Root Systems}

Water flow in a plant vessel is regulated by transpiration pressure and modulated by hydraulic resistance, which is influenced by the length and diameter of the vessel as well as the flow rate. The relationship between water pressure and resistance is analogous in many respects to an electrical circuit (i.e., the voltage and electrical resistance of Ohm's law) [38]. In the soil-plant-atmosphere system, which specifies the hydraulic sequence from root uptake to leaf transpiration, water behaviour is also analogous to an electrical circuit. The soybean root system has many lateral fine roots and exhibits synthetic resistance, but not serial resistance. This needs to be considered when calculating total hydraulic resistance. If a large leaf area generates more transpiration pressure, and if a root system develops more branches or tips, then the total hydraulic resistance would be expected to decrease.

The correlation analyses of the H/A ratio for root hydraulic conductivity and the H/A ratios of morphological characteristics indicated that leaf area, thick-root length, and number of root tips had a close relationship with root hydraulic conductivity. This finding suggests that hypoxia-induced changes to leaf area, thick-root length, and number of root tips are associated with root hydraulic conductivity. Thus, if the leaf area decreases because of hypoxic injury, the root hydraulic conductivity also decreases. This is likely because of reduced transpiration, although this parameter was not assessed in this study. Regarding root traits, when the thick-root length and number of root tips decreased because of exposure to hypoxic conditions, the root hydraulic conductivity also decreased (Figure 2(B) Figure 2(C)), as expected according to Ohm's law.

Root system morphology might regulate root hydraulic conductivity, in agreement with Ohm's law, in many soybean cultivars. However, root hydraulic conductivity must be regulated not only by root quantity, but also by root water permeability. In radish, water absorption depends mostly on the water channels of the root tissue cells [39]. Furthermore, in soybean roots, the production of an aquaporin, which is a plasma membrane intrinsic protein, varies under hypoxic 
conditions [40]. Consequently, the changes in the abundance of aquaporin-like proteins in response to hypoxia were studied for each cultivar.

\subsection{Cultivar-Specific Changes to the Plasma Membrane Intrinsic Proteins in the Water Channels of Soybean Roots}

Plant water channels consist primarily of two kinds of membrane intrinsic proteins, namely PIP and TIP. In the present study, the abundance of the following four aquaporin proteins were examined immunologically: PIP1s (PIP1;1, 1;2, and 1;3), PIP2s ('PIP2;1, 2;2, and 2;3), TIP1s (TIP1;1 and TIP1;2), and TIP2 (TIP2;1). The PIP2s and TIP2 proteins exhibit greater hydraulic activity than PIP1s [41] [42], although PIP1; 1 considerably enhances PIP2; 1 hydraulic activities [43]. The PIP1s aquaporins may affect a regulator of heteromerization and fine-tuning of the channel activity of the aquaporin complex along with PIP2 [44].

The anti-PIP1s antibodies detected five bands in immunoblots (i.e., 24.3, 27.1, 32.3, 41.3 - 50.8, and $67.7-108.5 \mathrm{kDa}$ ) (Figure 3). The monomeric form of the Arabidopsis thaliana aquaporin is $28.0 \mathrm{kDa}$ (Cosmo Bio Co., Ltd.). Thus, the $27.1 \mathrm{kDa}$ band may represent the original size of the PIP1s monomers, while the 41.3 - 50.8- and 67.7 - $108.5 \mathrm{kDa}$ bands might correspond to the dimeric and trimeric/tetrameric forms, respectively. The $32.3 \mathrm{kDa}$ band is likely a chemically modified aquaporin-like protein, and not a multimeric form.

A correlation between the $\mathrm{H} / \mathrm{A}$ ratio of the $32.3 \mathrm{kDa} \mathrm{PIP} 1 \mathrm{~s}$ and the $\mathrm{H} / \mathrm{A}$ ratio of root hydraulic conductivity was observed (Figure 2(D) and Figure 3), indicating the possibility of a close relationship between hypoxia tolerance and aquaporin-like protein production. The suppressed expression of the tobacco aquaporin gene $N t A Q P 1$ was associated with decreased transpiration activity and root hydraulic conductivity [45]. The abundance of the $32.3 \mathrm{kDa}$ PIP1s significantly increased in the hypoxia-tolerant "S32" plants under hypoxic conditions. Additionally, root hydraulic conductivity may also have increased in these plants because of the influence of abundant aquaporin-like proteins in addition to root morphology changes. The field waterlogging tolerance of "S32" plants was not attributed to the formation of aerenchymatous cells [19], which is in contrast to many other soybean cultivars [14] [16]. A relationship between hypoxia tolerance and aquaporin-like protein production was still observed even if the "S32" data were not considered. Thus, responses to hypoxia depend on the regulation of PIP1s, possibly by different mechanisms among cultivars. Matsuo et al. described a relationship between hypoxia and changes to mRNA levels for the "Ere" soybean root aquaporin PIP2 gene GmPIP2; 2 [40]. The expression of this gene was downregulated in roots after a 3-h exposure to hypoxic conditions. Although the aquaporins and durations of hypoxia treatment were different from those used in the present study, the fact that the external hypoxic conditions influenced the production of PIP proteins and consequently affected root water uptake was consistent in both studies.

The production of PIP1s aquaporin-like proteins did not differ between aero- 
bic and hypoxic conditions for five cultivars (i.e., "KJi", "STs", "THa", "TKu", and "TMu"). In these cultivars, the changes in the membrane water channels of the root system had considerable effects on root hydraulic conductivity. This suggests that PIP proteins are not the main factor responsible for the quantitative changes caused by hypoxia in some cultivars. In $A$. thaliana roots subjected to anoxic conditions, the aquaporin gating activity is regulated by cytosolic $\mathrm{pH}$ [46]. This implies that the hydraulic activity of water channels should be investigated even if there is no change in aquaporin production. Moreover, the importance of root hydraulic conductivity for water channel-induced permeability needs to be investigated among cultivars with specific hypoxic responses (e.g., examining the effects of aquaporin inhibitors such as silver nitrate or mercury compounds) [47]. Furthermore, hypoxia-inducible root-related transcription factors [48], fibrillins [49], nuclear-related proteins [50], and the special fermentative metabolic system in soybean roots [51] [52] may affect cultivar-specific waterlogging tolerance and will also need to be studied to further characterize the mechanism underlying waterlogging tolerance.

\section{Acknowledgements}

This study was supported by Japan Society for the Promotion of Science KAKENHI grants (22688002 and 26450015). I extend my appreciation to Dr. F. Kousaka of the Hokkaido Central Agricultural Experiment Station for providing the "Shoku-kei32" (\#25164) seeds and helpful suggestions. I thank Prof. J. Abe of the Research Faculty of Agriculture, Hokkaido University and Dr. J. Ishikawa-Sakurai of the Institute of Crop Science, National Agriculture and Food Research Organization for advice on the experimental design and data interpretation. I also thank Mr. S. Ichikawa of the Field Science Center for the Northern Biosphere, Hokkaido University for assisting with the preparation of the experimental system.

\section{References}

[1] Ahmed, F., Rafii, M.Y., Ismail, M.R., Juraimi, A.S., Rahim, H.A., Asfaliza, R. and Latif, M.A. (2013) Waterlogging Tolerance of Crops: Breeding, Mechanism of Tolerance, Molecular Approaches, and Future Prospects. BioMed Research International, 2013, Article ID: 963525. https://doi.org/10.1155/2013/963525

[2] E-STAT (2016) Portal Site of Official Statistics of Japan. http://www.e-stat.go.jp/SG1/estat/List.do?lid=000001141136

[3] Takahashi, M., Hosokawa, H. and Matsuzaki, M. (2006) $\mathrm{N}_{2}$ Fixation of Nodules and N Absorption by Soybean Roots Associated with Ridge Tillage on Poorly Drained Upland Fields Converted from Rice Paddy Fields. Soil Science and Plant Nutrition, 52, 291-299. https://doi.org/10.1111/j.1747-0765.2006.00037.x

[4] Yoshinaga, S. (2012) Improvement of Soybean Growth and Yield (Glycine max L.) by Inter-Row Stripe Tillage in Upland Fields Converted from Paddy Fields. Japan Agricultural Research Quarterly, 46, 115-121. https://doi.org/10.6090/jarq.46.115

[5] Shimada, S., Hamaguchi, H., Kim, Y., Matsuura, K., Kato, M., Kokuryu, T., Tazawa, J. and Fujimori, S. (2012) Effects of Water Table Control by Farm-Oriented En- 
hancing Aquatic System on Photosynthesis, Nodule Nitrogen Fixation and Yield of Soybeans. Plant Production Science, 15, 132-143. https://doi.org/10.1626/pps.15.132

[6] Kokubun, M. (2013) Genetic and Cultural Improvement of Soybean for Waterlogged Conditions in Asia. Field Crops Research, 152, 3-7.

https://doi.org/10.1016/j.fcr.2012.09.022

[7] Tian, X.-H., Nakamura, T. and Kokubun, M. (2005) The Role of Seed Structure and Oxygen Responsiveness in Pre-Germination Flooding Tolerance of Soybean Cultivars. Plant Production Science, 8, 157-165. https://doi.org/10.1626/pps.8.157

[8] Jitsuyama, Y., Hagihara, Y. and Konno, Y. (2014) Two Imbibition Properties Independently Influence the Cultivar-Specific Flooding Tolerance of Dried Soybean Seeds. Seed Science Research, 24, 37-48. https://doi.org/10.1017/S0960258513000378

[9] Oosterhuis, D.M., Scott, H.D., Hampton, R.E. and Wullschleger, S.D. (1990) Physiological Responses of Two Soybean (Glycine max (L.) Merr.) Cultivars to Short-Term Flooding. Environmental and Experimental Botany, 30, 85-92. https://doi.org/10.1016/0098-8472(90)90012-S

[10] Sung, F.J.M. (1993) Waterlogging Effect on Nodule Nitrogenase and Leaf Nitrate Reductase Activities in Soybean. Field Crops Research, 35, 183-189. https://doi.org/10.1016/0378-4290(93)90152-D

[11] Board, J.E. (2008) Waterlogging Effects on Plant Nutrient Concentrations in Soybean. Journal of Plant Nutrition, 31, 828-838. https://doi.org/10.1080/01904160802043122

[12] Bacanamwo, M. and Purcell, L.C. (1999) Soybean Dry Matter and N Accumulation Responses to Flooding Stress, N Sources and Hypoxia. Journal of Experimental Botany, 50, 689-696. https://doi.org/10.1093/jxb/50.334.689

[13] Sauter, M. (2013) Root Responses in Flooding. Current Opinion in Plant Biology, 16, 282-286. https://doi.org/10.1016/j.pbi.2013.03.013

[14] Shimamura, S., Yamamoto, R., Nakamura, T., Shimada, S. and Komatsu, S. (2010) Stem Hypertrophic Lenticels and Secondary Aerenchyma Enable Oxygen Transport to Roots of Soybean in Flooded Soil. Annals of Botany, 106, 277-284. https://doi.org/10.1093/aob/mcq123

[15] Matsukawa, I., Tanimura, Y., Teranishi, R. and Banba, H. (1983) Varietal Difference of Resistance to Excess Wet Injury of Soybean in Dry Field Converted from Paddy Rice Field. Research Bulletin of Hokkaido Prefecture Agricultural Experimental Station, 49, 32-40. (In Japanese, with Summary in English)

[16] Thomas, A.L., Guerreiro, S.M.C. and Sodek, L. (2005) Aerenchyma Formation and Recovery from Hypoxia of the Flooded Root System of Nodulated Soybean. Annals of Botany, 96, 1191-1198. https://doi.org/10.1093/aob/mci272

[17] Jitsuyama, Y. (2013) Responses of Japanese Soybeans to Hypoxic Condition at Rhizosphere Were Different Depending Upon Cultivars and Ambient Temperatures. American Journal of Plant Science, 4, 1297-1308.

https://doi.org/10.4236/ajps.2013.46161

[18] Jitsuyama, Y. (2015) Morphological Root Responses of Soybean to Rhizosphere Hypoxia Reflect Waterlogging Tolerance. Canadian Journal of Plant Science, 95, 999-1005. https://doi.org/10.4141/cjps-2014-370

[19] Kousaka, F., Ohnishi, S., Nakamura, T., Hiraga, S., Maekawa, T., Shimada, S. and Fujita, S. (2013) Response of Soybean (Glycine max) Waterlogging-Tolerant Variety Shoku-kei32 to Short-Term Soil Flooding. 11 th Conference of the International Society for Plant Anaerobiosis, Los Baños, 6-11 October 2013, 121. 
[20] Hokkaido Research Organization, Agriculture Research Department Central Agricultural Experiment Station (HCAES) (2009) Results Outline in 2009. General Topic. Field Survey for Soybean Waterlogging Tolerance after the Blooming Stage. (In Japanese)

https://www.hro.or.jp/list/agricultural/center/kenkyuseika/gaiyosho/h21gaiyo/f3/00 2.pdf

[21] Fehr, W.R., Caviness, C.E., Burmood, D.T. and Pennington, J.S. (1971) Stage of Development Descriptions for Soybeans, Glycine max (L.) Merrill. Crop Science, 11, 929-931. https://doi.org/10.2135/cropsci1971.0011183X001100060051x

[22] Kaneko, T., Horie, T., Nakahara, Y., Tsuji, N., Shibasaka, M. and Katsuhara, M. (2015) Dynamic Regulation of the Root Hydraulic Conductivity of Barley Plants in Response to Salinity/Osmotic Stress. Plant and Cell Physiology, 56, 875-882. https://doi.org/10.1093/pcp/pcv013

[23] Emery, R.J.N. and Salon, C. (2002) Water Entry into Detached Root Systems Saturates with Increasing Externally Applied Pressure: A Result Inconsistent with Models of Simple Passive Diffusion. Physiologia Plantarum, 115, 406-416. https://doi.org/10.1034/j.1399-3054.2002.1150311.x

[24] Hanba, T.Y., Shibasaka, M., Hayashi, Y., Hayakawa, T., Kasamo, K., Terashima, I. and Katsuhara, M. (2004) Overexpression of the Barley Aquaporin HvPIP2. 1 Increases Internal $\mathrm{CO}_{2}$ Conductance and $\mathrm{CO}_{2}$ Assimilation in the Leaves of Transgenic Rice Plants. Plant and Cell Physiology, 45, 521-529.

https://doi.org/10.1093/pcp/pch070

[25] Bradford, M.M. (1976) A Rapid and Sensitive Method for the Quantitation of Microgram Quantities of Protein Utilizing the Principle of Protein-Dye Binding. Analytical Biochemistry, 72, 248-254. https://doi.org/10.1016/0003-2697(76)90527-3

[26] Laemmli, U.K. (1970) Cleavage of Structural Proteins during the Assembly of the Head of Bacteriophage. Nature, 227, 680-685. https://doi.org/10.1038/227680a0

[27] Sallam, A. and Scott, H.D. (1987a) Effects of Prolonged Flooding on Soybean at the R2 Growth Stage: I. Dry Matter and N and P Accumulation. Journal of Plant Nutrition, 10, 567-592.

[28] Tjepkema, J.D. and Yocum, C.Y. (1973) Respiration and Oxygen Transport in Soybean Nodules. Planta, 115, 59-72. http://www.jstor.org/stable/23370889 https://doi.org/10.1007/BF00388605

[29] Letey, J. and Stolzy, L.H. (1967) Limiting Distances between Root and Gas Phase for Adequate Oxygen Supply. Soil Science, 103, 404-409. https://doi.org/10.1097/00010694-196706000-00006

[30] Boru, G., Vantoai, T., Alves, J., Hua, D. and Knee, M. (2003) Response of Soybean to Oxygen Deficiency and Elevated Root-Zone Carbon Dioxide Concentration. Annals of Botany, 91, 447-453. https://doi.org/10.1093/aob/mcg040

[31] Greenway, H., Armstrong, W. and Colmer, T.D. (2006) Condition Leading to High $\mathrm{CO}_{2}(>5 \mathrm{kPa})$ in Waterlogged-Flooded Soils and Possible Effects on Root Growth and Metabolism. Annals of Botany, 98, 9-32. https://doi.org/10.1093/aob/mcl076

[32] Irving, L.J., Sheng, Y.B., Woolley, D. and Matthew, C. (2007) Physiological Effects of Waterlogging on Two Lucerne Varieties Grown under Glasshouse Conditions. Journal of Agronomy and Crop Science, 193, 345-356. https://doi.org/10.1111/j.1439-037X.2007.00277.x

[33] Wiengweera, A., Greenway, H. and Thomson, C.J. (1997) The Use of Agar Nutrient Solution to Simulate Lack of Convection in Waterlogged Soils. Annals of Botany, 80, 115-123. http://www.jstor.org/stable/42765468 https://doi.org/10.1006/anbo.1996.0405 
[34] Bouma, T.J., Nielsen, K.L., Eissenstat, D.M. and Lynch, J.P. (1997) Soil $\mathrm{CO}_{2}$ Concentration Does Not Affect Growth or Root Respiration in Bean and Citrus. Plant, Cell and Environment, 20, 1495-1505. https://doi.org/10.1046/j.1365-3040.1997.d01-52.x

[35] Moldovan, D., Spriggs, A., Yang, J., Pogson, B.J., Dennis, E.S. and Wilson, I.W. (2010) Hypoxia-Responsive microRNAs and trans-Acting Small Interfering RNAs in Arabidopsis. Journal of Experimental Botany, 61, 165-177. https://doi.org/10.1093/jxb/erp296

[36] Sairam, R.K., Kumutha, D., Ezhilmathi, K., Deshmukh, P.S. and Srivastava, G.C. (2008) Physiology and Biochemistry of Waterlogging Tolerance in Plants. Biologia Plantarum, 52, 401-412. https://doi.org/10.1007/s10535-008-0084-6

[37] Sallam, A. and Scott, H.D. (1987b) Effects of Prolonged Flooding on Soybeans during Early Vegetative Growth. Soil Science, 144, 61-66. https://doi.org/10.1097/00010694-198707000-00010

[38] Kramer, P.J. and Boyer, J.S. (1995) Historical Review, Some General Concepts, Soil-Plant-Atmosphere Continuum and Ohm's Law Analogy. In: Kramer, P.J. and Boyer, J.S., Eds., Water Relations of Plants and Soils, Academic Press, London, 9.

[39] Suga, S., Murai, M., Kuwagata, T. and Maeshima, M. (2003) Differences in Aquaporin Levels among Cell Type of Radish and Measurement of Osmotic Water Permeability of Individual Protoplasts. Plant and Cell Physiology, 44, 277-286. https://doi.org/10.1093/pcp/pcg032

[40] Matsuo, N., Nanjo, Y., Tougou, M., Nakamura, T., Nishizawa, K., Komatsu, S. and Shimamura, S. (2012) Identification of Putative Aquaporin Genes and Their Expression Analysis under Hypoxic Conditions in Soybean (Glycine max (L.) Merr.). Plant Production Science, 15, 278-283. https://doi.org/10.1626/pps.15.278

[41] Lopez, F., Bousser, A., Sissoëff, I., Hoarau, J. and Mahé, A. (2004) Characterization in Maize of ZmTIP2-3, a Root-Specific Tonoplast Intrinsic Protein Exhibiting Aquaporin Activity. Journal of Experimental Botany, 55, 539-541. https://doi.org/10.1093/jxb/052

[42] Suga, S. and Maeshima, M. (2004) Water Channel Activity of Radish Plasma Membrane Aquaporins Heterologously Expressed in Yeast and Their Modification by Site-Directed Mutagenesis. Plant and Cell Physiology, 45, 823-830. https://doi.org/10.1093/pcp/pch120

[43] Liu, C., Fukumoto, T., Matsumoto, T., Gena, P., Frascaria, D., Kaneko, T., Katsuhara, M., Zhong, S., Sun, X., Zhu, Y., Iwasaki, I., Ding, X., Calamita, G. and Kitagawa, Y. (2013) Aquaporin OsPIP1. 1 Promotes Rice Salt Resistance and Seed Germination. Plant Physiology and Biochemistry, 63, 151-158. https://doi.org/10.1016/j.plaphy.2012.11.018

[44] Yaneff, A., Vitali, V. and Amodeo, G. (2015) PIP1 Aquaporins: Intrinsic Water Channels or PIP2 Aquaporin Modulators? FEBS Letters, 589, 3508-3515. https://doi.org/10.1016/j.febslet.2015.10.018

[45] Siefritz, F., Tyree, M.T., Lovisolo, C., Schubert, A. and Kaldenhoff, R. (2002) PIP1 Plasma Membrane Aquaporins in Tobacco: From Cellular Effects to Function in Plants. The Plant Cell, 14, 869-876. https://doi.org/10.1105/tpc.000901

[46] Tournaire-Roux, C., Sutka, M., Javot, H., Gout, E., Gerbeau, P., Luu, D.T., Bligny, R. and Maurel, C. (2003) Cytosolic pH Regulates Root Water Transport during Anoxic Stress through Gating of Aquaporins. Nature, 425, 393-397. https://doi.org/10.1038/nature01853

[47] Sadok, W. and Sinclair, T.R. (2010) Genetic Variability of Transpiration Response of Soybean (Glycine max (L.) Merr.) Shoots to Leaf Hydraulic Conductance Inhibi- 
tor $\mathrm{AgNO}_{3}$. Crop Science, 50, 1423-1430.

https://doi.org/10.2135/cropsci2009.10.0575

[48] Valliyodan, B., Van Toai, T.T., Alves, J.D., Goulart, P.D.P., Lee, J.D., Fritschi, F.B., Rahman, M.A., Islam, R., Shannon, J.G. and Nguyen, H.T. (2014) Expression of Root-Related Transcription Factors Associated with Flooding Tolerance of Soybean (Glycine max). International Journal of Molecular Sciences, 15, 17622-17643. https://doi.org/10.3390/ijms151017622

[49] Mutava, R.N., Prince, S.J.K., Syed, N.H., Song, L., Valliyodan, B., Chen, W. and Nguyen, H.T. (2015) Understanding Abiotic Stress Tolerance Mechanisms in Soybean: A Comparative Evaluation of Soybean Response to Drought and Flooding Stress. Plant Physiology and Biochemistry, 86, 109-120. https://doi.org/10.1016/j.plaphy.2014.11.010

[50] Komatsu, S., Hiraga, S. and Nouri, M.Z. (2014) Analysis of Flooding-Responsive Proteins Localized in the Nucleus of Soybean Root Tips. Molecular Biology Reports, 41, 1127-1139. https://doi.org/10.1007/s11033-013-2959-7

[51] Borella, J., do Amarante, L., de Olibeira, D.D.C., de Olibeira, A.C.B. and Braga, E.J.B. (2014) Waterlogging-Induced Changes in Fermentative Metabolism in Roots and Nodules of Soybean Genotypes. Scientia Agricola, 71, 499-508. https://doi.org/10.1590/0103-9016-2014-0044

[52] Jung, G., Matsunami, T., Oki, Y. and Kokubun, M. (2008) Effects of Waterlogging on Nitrogen Fixation and Photosynthesis in Supernodulating Soybean Cultivar Kanto 100. Plant Production Science, 11, 291-297. https://doi.org/10.1626/pps.11.291

\section{Abbreviations}

ANOVA, analysis of variance; Ere, Enrei; H/A ratio, ratio of hypoxic $(\mathrm{H})$ and aerobic (A) values; KJi, Koganejiro; Lp, root hydraulic conductivity; PIP, plasma membrane intrinsic protein; S32, Shoku-kei32; SMa, Suzumaru; STs, Shirotsurunoko; THa, Toyoharuka; THo, Toyohomare; TIP, tonoplast intrinsic protein; $\mathrm{TKu}$, Tanbakuro; TMu, Toyomusume. 


\section{Supplementary}
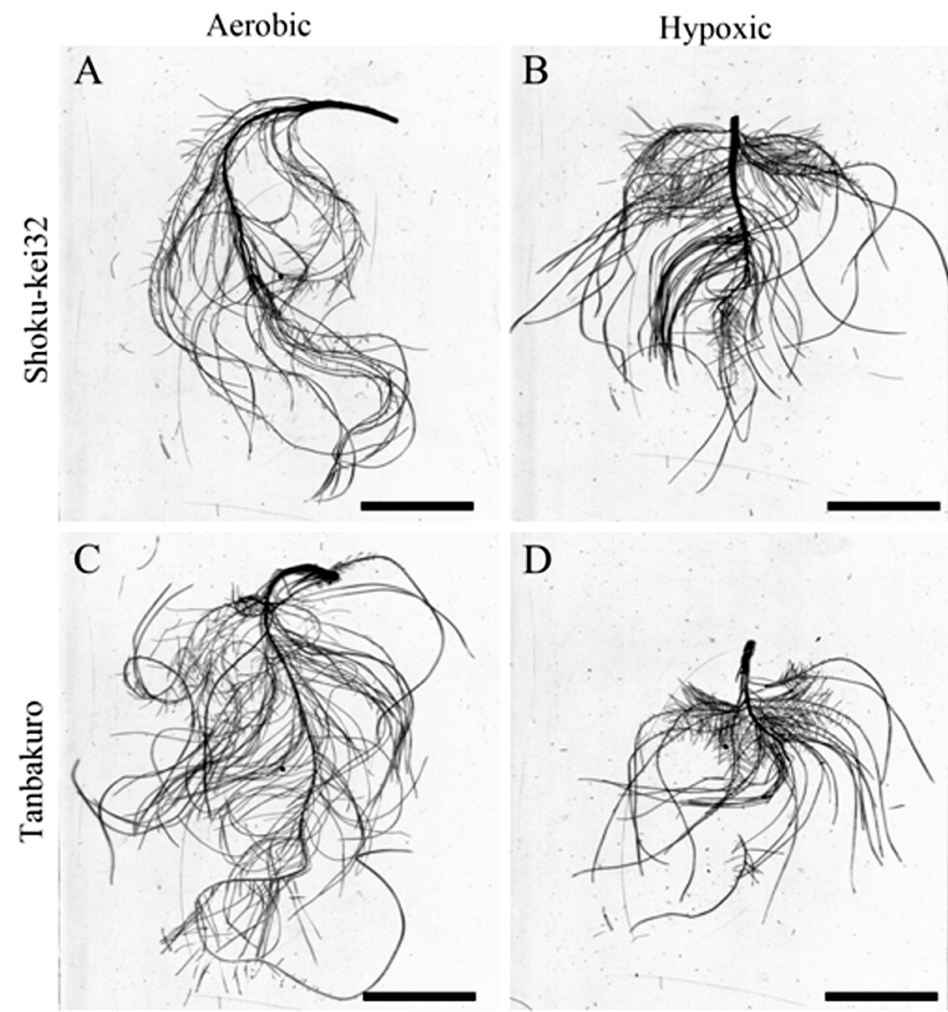

$\mathrm{D}$

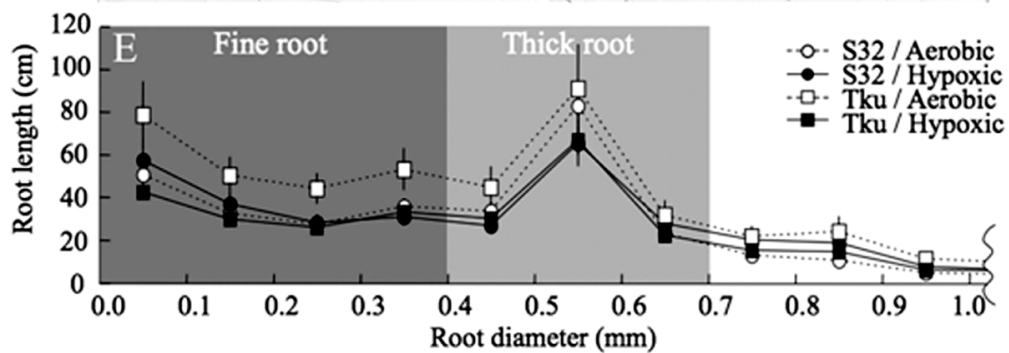

Supplementary Figure 1. Typical images of "Shoku-kei32" (A and B) and "Tanbakuro" $(\mathrm{C}$ and $\mathrm{D})$ roots under aerobic $(\mathrm{A}$ and $\mathrm{C})$ and hypoxic $(\mathrm{B}$ and $\mathrm{D})$ conditions. Scale bars represent $5 \mathrm{~cm}$. Root length frequencies for fine roots (diameter: $0.0-0.4 \mathrm{~mm}$ ) and thick roots (diameter: $0.4-0.7 \mathrm{~mm}$ ) (E). Vertical bars indicate standard errors.

Supplementary Table 1. Average band intensities for the immunoblot analysis of soluble proteins extracted from soybean roots.

\begin{tabular}{|c|c|c|c|c|c|c|c|c|c|c|c|}
\hline \multirow[b]{3}{*}{ ANOVA } & \multirow[b]{3}{*}{ df } & \multicolumn{10}{|c|}{ Molecular size of PIP1s proteins $(\mathrm{kDa})$} \\
\hline & & \multicolumn{2}{|c|}{$67.7-108.5$} & \multicolumn{2}{|c|}{$41.3-50.8$} & \multicolumn{2}{|c|}{32.3} & \multicolumn{2}{|c|}{27.1} & \multicolumn{2}{|c|}{24.3} \\
\hline & & MS & Sig. ${ }^{a}$ & MS & Sig. & MS & Sig. & MS & Sig. & MS & Sig. \\
\hline $\mathrm{T}$ & 1 & 253 & * & 779 & $* *$ & 119 & $\dagger$ & 688 & $* *$ & 1487 & $* *$ \\
\hline $\mathrm{C}$ & 8 & 333 & $* * *$ & 253 & $* *$ & 63 & $\dagger$ & 277 & $* *$ & 379 & $\dagger$ \\
\hline $\mathrm{C} \times \mathrm{T}$ & 8 & 40 & ns & 124 & ns & 26 & ns & 127 & ns & 578 & $* *$ \\
\hline
\end{tabular}

Analysis of variance was used to compare the variables among cultivars under different conditions; The mean square and significance values are provided; ${ }^{2}$ $\dagger,{ }^{*}, * *$, and ${ }^{* * *}$ in each row represent significance at $0.1,0.05,0.01$, and 0.001 probability levels, respectively; ns, not significant according to ANOVA ( $\mathrm{n}=$ 3); ANOVA, analysis of variance; df, degree of freedom; MS, mean square; Sig., significance. 
Submit or recommend next manuscript to SCIRP and we will provide best service for you:

Accepting pre-submission inquiries through Email, Facebook, LinkedIn, Twitter, etc. A wide selection of journals (inclusive of 9 subjects, more than 200 journals)

Providing 24-hour high-quality service

User-friendly online submission system

Fair and swift peer-review system

Efficient typesetting and proofreading procedure

Display of the result of downloads and visits, as well as the number of cited articles Maximum dissemination of your research work

Submit your manuscript at: http://papersubmission.scirp.org/

Or contact ajps@scirp.org 